\section{The Role of Syphilis Point-of-Care Testing in the Management of Patients with Genital Ulceration}

Hayward RS ${ }^{1}$, Boothby $\mathbf{M}^{1}$

\section{的

University Hospitals Birmingham WHS NHS Foundation Trust

${ }^{1}$ Whittall Street Clinic, University Hospitals Birmingham NHS Foundation Trust, Birmingham B4 6DH, UK

\section{Background}

Syphilis is a treatable condition caused by Treponema pallidum. ${ }^{1}$ Between 2013 and 2014 there was a 33\% increase in the diagnosis of infectious syphilis in the United Kingdom. ${ }^{2}$ With an increase of $46 \%$ amongst men who have sex with men (MSM). ${ }^{2}$

Syphilis Point-of-Care (POC) tests were originally developed to provide a quick, low cost alternative in countries with limited resources or facilities for routine serological testing. There are several syphilis POC tests available which are easy to operate, with minimal training and provide a result within 15-20 mins.

Many patients infected with syphilis may be asymptomatic, hence screening for treponemal serological testing of all attendees at our sexual health clinic is routine. Within our sexual health clinic a syphilis POC test is offered for any of the following reasons;

\section{Genital ulcer suggestive of chancre}

2. Generalized rash suggestive of secondary syphilis

3. Contact of syphilis

\section{Commercial sex workers}

\section{High risk asymptomatic patients who decline venous sample}

Patients with a history of previously positive syphilis serology or a previous history of syphilis infection are not offered a syphilis POC test. As part of a recent audit we reviewed whether offering a syphilis POC test to potentially high risk patients has any impact on management.

\section{Methoc}

Electronic patient records were searched between 1st October 2014 and 31st March 2015 at Whittall Street Clinic. Patients offered a syphilis POC test between these dates were identified. Using a previously tested audit data collection tool, information about patient demographics, indication for syphilis POC test and clinical diagnosis were collected and anonymised.

\section{Results}

111 records were identified as being offered a syphilis POC test, during a six month period. 13 records were excluded; 3 duplicate records and 10 patients were offered a syphilis POC test, but it was not performed. Of the remaining 98 records; 65 patients had a syphilis POC test done as indicated by our local guidelines. Of these 65 patients $86 \%$ (56) were male and 70\% (39) were MSM. The indication for doing a POC test is shown in Graph 1. Four patients had two indications for having a test done, e.g. the patient was a contact of syphilis and had a genital ulcer suggestive of a chancre.

\section{Graph 1 - Indication for syphilis Point-of-Care Test}

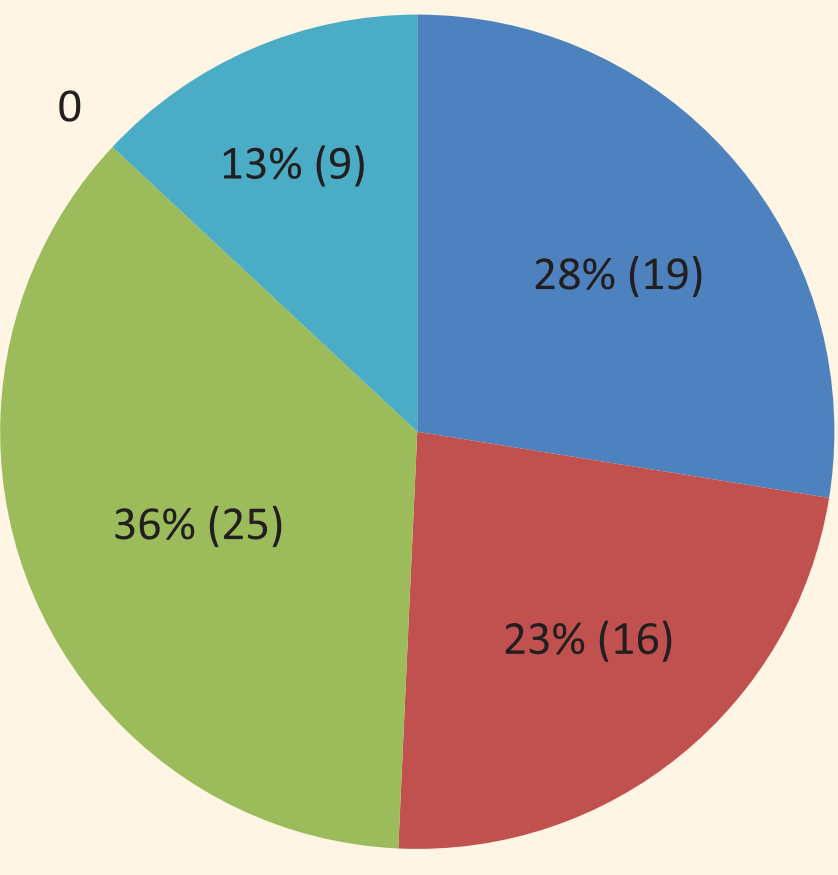

Genital ulcer suggestive of chancre

Rash suggestive of secondary syphilis

Contact of syphilis

Commercial sex worker

High risk asymptomatic patient who declined venepuncture
33 patients had a syphilis POC test done for a reason outside of local guidance, including one patient who was already known to have positive syphilis serology.

19 patients were suspected to have genital ulcer disease suggestive of a chancre and 9 of these patients were treated as primary syphilis. In patients with genital ulcer disease suspicious of a chancre the initial test in our clinic is dark ground microscopy, with syphilis Polymerase Chain Reaction (PCR) swab and serological testing also being performed.

Table 1 shows those 9 patients treated as primary syphilis and the results of any tests performed.

\begin{tabular}{|c|c|c|c|c|c|}
\hline Patient & $\begin{array}{c}\text { Dark } \\
\text { Ground }\end{array}$ & $\begin{array}{c}\text { Syphilis } \\
\text { PCR swab }\end{array}$ & $\begin{array}{c}\text { Syphilis } \\
\text { serology }\end{array}$ & POCT & Diagnosis \\
\hline $\mathbf{1}$ & Not done & Positive & Positive & Reactive & $\begin{array}{c}\text { Primary Syphilis - } \\
\text { treated on day }\end{array}$ \\
\hline $\mathbf{2}$ & Not done & Positive & Positive & $\begin{array}{c}\text { Non-re- } \\
\text { active }\end{array}$ & $\begin{array}{c}\text { Treated as HSV on } \\
\text { day, primary syphilis } \\
\text { treated 19 days later }\end{array}$ \\
\hline $\mathbf{3}$ & Negative & Positive & Positive & $\begin{array}{c}\text { Non-re- } \\
\text { active }\end{array}$ & $\begin{array}{c}\text { Primary Syphilis - } \\
\text { treated 8 days later }\end{array}$ \\
\hline $\mathbf{4}$ & Positive & Positive & Positive & Reactive & $\begin{array}{c}\text { Primary Syphilis - } \\
\text { treated on day }\end{array}$ \\
\hline $\mathbf{5}$ & Negative & Positive & Positive & Reactive & $\begin{array}{c}\text { Primary Syphilis - } \\
\text { treated on day }\end{array}$ \\
\hline $\mathbf{6}$ & Not done & Positive & Positive & Reactive & $\begin{array}{c}\text { Primary Syphilis - } \\
\text { treated on day }\end{array}$ \\
\hline $\mathbf{7}$ & Negative & Positive & Positive & Non-re- & $\begin{array}{c}\text { Primary Syphilis - } \\
\text { active } \\
\text { contacd on day as } \\
\text { request }\end{array}$ \\
\hline $\mathbf{8}$ & Negative & Negative & Negative & Non-re- \\
active & $\begin{array}{c}\text { ?Primary Syphilis - } \\
\text { treated on day at pa- } \\
\text { tient request, DNA'ed } \\
\text { F/U }\end{array}$ \\
\hline
\end{tabular}

The 3 highlighted patients were treated for primary syphilis on the day of presentation based on the result of the syphilis POC test, either because dark ground microscopy was not performed, or was negative.

\section{Discussion}

Syphilis POC test remains an important diagnostic tool in settings which have no on-site laboratory facilities. However it also has a role to play in a well-resourced setting, such as our clinic. It may be argued that typical symptoms or signs of primary syphilis would warrant treatment regardless of initial tests results. However a reactive syphilis POC can add strength to clinical judgement in cases which may be less typical of primary syphilis.

\section{References}

1. Schaudinn F and Hoffmann E. Bericht Über das Vorkommen von Spirochaeten in syphilitischen Krankheitsprodukten und bei Papilloten. Arb Kaiserl Gesurndheisamte 1905; 22: 527-532.

2.Public Health England. Sexually transmitted infections and chlamydia screening in England 2014. Health Protection Rep 2014; 9: 22-29. 